\title{
Nutrition value of Viburnum L. (Adoxaceae) fruits
}

\author{
Vladimir Sorokopudov ${ }^{1 *}$, Alla Kuklina ${ }^{2}$, Alexey Sakhonenko ${ }^{1}$, Olga Sorokopudova ${ }^{1}$, and \\ Nadezhda Nazaryuk $^{3}$ \\ ${ }^{1}$ Russian State Agricultural University, K.A. Timiryazev Moscow Agricultural Academy, 127550, \\ Moscow, Russia \\ ${ }^{2}$ N.V. Tsitsin's Main Botanical Garden of the Russian Academy of Sciences, 127276, Moscow, \\ Russian Federation \\ ${ }^{3}$ Federal State Budgetary Scientific Institution of the Federal Altai Scientific Center for Agricultural \\ Biotechnologies, 656910, Barnaul, Russia
}

\begin{abstract}
The study of the chemical composition of fruits and seeds in some types of viburnum fruits and the identification of chemical elements localization in their various parts by the energy-dispersion analysis on an electronic ion-raster scanning microscope Quanta 200 3D are presented in this contribution. Elemental analysis of fruits and seeds of viburnum species allowed, for the first time, identifying 10 chemical elements in their composition, and these are oxygen, carbon, nitrogen, sodium, magnesium, silicon, phosphorus, sulfur, potassium and calcium. Different parts of fruits and seeds differ in the percentage of individual chemical elements in them.
\end{abstract}

Keywords: Viburnum L., scanning electron microscopy, elemental composition, medical plant.

\section{Introduction}

There are about 200 known species in genus Viburnum (Viburnum L., Adoxaceae). Viburnum is essential as a medicinal plant. The fruits, as well as its processing products, have medicinal properties. They are used as a mild laxative and diaphoretic, as well as for headaches. Viburnum berry infusions are used in the treatment of gastric and duodenal ulcer, and heartaches.

The study of the elemental composition of plants is necessary for a more complete characterization of chemical elements distribution in natural and anthropogenic landscapes, since plants are the most important link in the biological cycle of substances. By the present, more than 70 chemical elements have been found in plants. The plant body bulk (about $90-95 \%$ of dry matter) consists of three elements assimilated during photosynthesis, and these are carbon, oxygen and hydrogen. The remaining 5-10\% of dry substances are mineral elements, such as nitrogen, phosphorus, calcium, potassium, magnesium, sulfur, silicon, iron, sodium, chlorine and aluminum. As a result of spectral analysis of the ash of various fruit plants, it was found that it contains from 17 to 24 micro- and macronutrients. Of the macronutrients, fruits of various plants contain phosphorus, sodium, silicon,

\footnotetext{
* Corresponding author: sorokopud2301@mail.ru
} 
magnesium, calcium, iron and potassium. On the average, wild-growing fruits contain 1.7$9.6 \mathrm{mg} \%$ aluminum, 4.7-28.5 $\mathrm{mg} \%$ sodium, 8.0-32.6 $\mathrm{mg} \%$ iron, 43.0-84.5 $\mathrm{mg} \%$ silicon, $16.3-31.1 \mathrm{mg} \%$, magnesium, $80-326 \mathrm{mg} \%$ calcium and $200-460 \mathrm{mg} \%$ potassium per raw substance. The qualitative composition and quantitative content of individual elements in fruits are different, and it is explained both by the biological characteristics of plant species and by the possible unevenness in the structure of the soils they grow on [1-11].

The aim of our work was studying the chemical composition of fruits and seeds in some types of viburnum fruits to identify the localization of chemical elements in their various parts.

\section{Objects and methods of investigations}

Viburnum species of various ecological and geographical origin were introduced in the Botanical Garden of the Belgorod State National Research University, R. I. Schroeder Arboretum of the Timiryazev Russian State Agricultural University and the Tsitsin State Agricultural Academy of the Russian Academy of Sciences in order to identify the most promising species and samples for the production and use in food industry. In the period from 2010 to 2020, we studied some species on a complex of economically valuable characteristics.

The study of the elemental composition of fruits and seeds in viburnum species of different genetic origin was carried out. At the same time, the fruit skin and pulp, seed skin and seed endosperm were analyzed separately. The study was carried out by the method of energy-dispersion analysis on an electron ion-raster scanning microscope Quanta 200 3D. The energy-dispersion microanalysis system is designed for the spectral analysis of characteristic secondary radiation in a scanning electron microscope. The quanta are emitted by the substance atoms during relaxation after the excitation by primary beam electrons. The quantum energy is equal to the energy difference between the shells on which the transitions occur. Since the electron level energies are quantized and strictly determined for each element of the periodic table, it is possible to determine, with a sufficient degree of accuracy, the set of elements that make up the sample under study and form this spectrum. The concentration of the corresponding element can be determined by the spectrum line intensity [12]. The method used allows us to identify the elements distribution features in different parts of plants. The results obtained give an idea of the content of a particular element in weight percentages (Wt \%) of the total number of elements at a given point in the sample $(100 \mathrm{Wt} \%)$.

\section{Results and discussion}

Analysis of viburnum fruits showed that the main part of their elemental composition is carbon and oxygen (Table 1). In addition to these two main elements, the fruits contain different weight percentages of sodium, magnesium, silicon, phosphorus, sulfur, potassium and calcium.

In the fruit pulp, the weight fraction of oxygen and carbon ranged from 95.76 to 97.47 $\mathrm{Wt} \%$. The remaining elements content ranged from 2.53 to $4.24 \mathrm{Wt} \%$. The magnesium proportion ranged from 0.06 to $0.09 \mathrm{Wt} \%$, that of phosphorus $-0.07 \mathrm{Wt} \%$, potassium 0.06 to $1.37 \mathrm{Wt} \%$, calcium -0.07 to $0.29 \mathrm{Wt} \%$ and silicon $-0.05 \mathrm{Wt} \%$. Sodium was also found in the fruit pulp.

The weight percentage of potassium content in the pulp of viburnum fruits is significantly lower $(0.06-1.37 \mathrm{Wt} \%)$ than that in their seeds $(0.08-3.72 \mathrm{Wt} \%)$. It is known that potassium regulates the carbon transport in a plant organism, as a result of which the 
amount of sugars in the fruits increases during their ripening.

Table 1. Chemical composition of viburnum fruit pulp, Wt \%

\begin{tabular}{|c|c|c|c|c|c|}
\hline Element & V.trifoliata & V. buriensis & V. prunifolia & V. lantana & $\begin{array}{c}\text { V. lantana } \\
\text { canadensis }\end{array}$ \\
\hline $\mathrm{C}$ & 74.08 & 70.19 & 68.49 & 70.21 & 49.42 \\
\hline $\mathrm{O}$ & $17-15$ & 16.80 & 14.36 & 19.75 & 44.04 \\
\hline $\mathrm{Na}$ & 0.06 & - & - & - & - \\
\hline $\mathrm{Mg}$ & 0.09 & - & - & 0.06 & - \\
\hline $\mathrm{N}$ & 7.24 & 12.72 & 17.15 & 9.88 & - \\
\hline $\mathrm{Si}$ & - & - & - & 0.05 & - \\
\hline $\mathrm{P}$ & - & - & - & - & 0.07 \\
\hline $\mathrm{K}$ & 1.37 & 0.06 & - & - & 1.08 \\
\hline $\mathrm{Ca}$ & - & 0.10 & - & - & 0.40 \\
\hline
\end{tabular}

Table 2. Chemical composition of viburnum seeds, Wt $\%$

\begin{tabular}{|c|c|c|c|c|c|c|c|c|c|c|}
\hline \multirow{2}{*}{ Element } & \multicolumn{9}{|c|}{ Seed peel } & \multicolumn{5}{c|}{ Endosperm } \\
\cline { 2 - 12 } & $\mathbf{1}$ & $\mathbf{2}$ & $\mathbf{3}$ & $\mathbf{4}$ & $\mathbf{5}$ & $\mathbf{1}$ & $\mathbf{2}$ & $\mathbf{3}$ & $\mathbf{4}$ & $\mathbf{5}$ \\
\hline $\mathrm{C}$ & 58.64 & 56.70 & 57.73 & 58.64 & 70.31 & 63.23 & 65.55 & 63.70 & 64.33 & 62.81 \\
\hline $\mathrm{O}$ & 35.98 & 36.96 & 37.50 & 37.20 & 15.14 & 25.48 & 23.25 & 27.49 & 23.09 & 27.70 \\
\hline $\mathrm{Na}$ & - & 0.09 & - & - & - & 0.05 & - & 0.04 & - & - \\
\hline $\mathrm{Mg}$ & 0.10 & 0.05 & - & - & - & 0.16 & - & 0.04 & - & - \\
\hline $\mathrm{Si}$ & - & 0.04 & - & - & - & - & 0.10 & - & - & - \\
\hline $\mathrm{P}$ & - & - & - & - & - & 0.12 & 0.09 & 0.23 & 0.66 & 0.12 \\
\hline $\mathrm{S}$ & - & - & - & - & - & 0.17 & 0.17 & 0.28 & 0.98 & 0.10 \\
\hline $\mathrm{K}$ & 0.30 & 0.08 & 0.30 & - & - & 0.24 & 0.42 & 0.75 & 3.72 & 0.47 \\
\hline $\mathrm{Ca}$ & - & - & - & 0.35 & - & 0.58 & 0.40 & 0.50 & 1.90 & 0.45 \\
\hline $\mathrm{N}$ & 4.97 & 6.08 & 4.46 & 3.81 & 14.55 & 7.97 & 10.02 & 6.97 & 5.32 & 8.32 \\
\hline
\end{tabular}

$1-V$. trifoliata, $2-$ V. buriensis, $3-$ V. prunifolia, $4-$ V. lantana, $5-$ V. lantana var. c anadensis.

Calcium is part of the structure and is necessary to maintain the functional integrity of cell membranes, and the protoplasm water-holding capacity largely depends on its amount. It is due to the fact that calcium is involved in the cell tissue construction and its content is the highest of all elements (except oxygen and carbon). In our studies, calcium accounted for 0.10 to $1.90 \mathrm{Wt} \%$ in various parts of viburnum fruits and seeds (Tables 1-2). Magnesium is known to be an essential component of chlorophyll. It participates in the conversion of carbohydrates due to the ability to activate the corresponding enzymes, increases the synthesis of vitamins $\mathrm{A}$ and $\mathrm{C}$. When the fruits ripen, the magnesium content in their pulp steadily decreases. The elemental analysis of various parts of viburnum fruits showed that the highest weight percentage of magnesium is contained in the seed endosperm (0.40-1.90 Wt \%) and fruit pulp (0.10-0.40 Wt\%). Phosphorus is involved in the metabolism, cell division, reproduction, transmission of hereditary properties and in other complex processes occurring in the plant. It is a part of complex proteins (nucleoproteins), nucleic acids, phosphatides, enzymes, vitamins, phytin and other biologically active agents. The study showed that phosphorus is present in the viburnum endosperm (0.09-0.98 Wt \%).

Sulfur (0.10-0.98 Wt\%) was also found in the viburnum endosperm. This element is a part of proteins (aminoacids - methionine, cystine and its derivative cysteine) and vitamins 
(thiamine $\mathrm{B} 1$ and biotin $\mathrm{H}$ ), participates in the formation of most enzymes and essential oils (garlic, onion, mustard, etc.). It plays an important role in the redox reactions of crops. Sulfur also increases crops resistance to low or high temperatures, drought and radiation. Due to its multifarious value, sulfur cannot be replaced by other mineral nutrition elements.

\section{Conclusion}

The elemental analysis of fruits and seeds of viburnum species allowed, for the first time, identifying 10 chemical elements as part of their composition, and these are oxygen, carbon, nitrogen, sodium, magnesium, silicon, phosphorus, sulfur, potassium and calcium. Different parts of fruits and seeds differ in the percentage of individual chemical elements in them.

\section{References}

1. E.A. Adamenko, On some ecobiological peculiarities of genus Viburnum, Bullet. of I.S. Kosenko Bot. Garden, KSAU, 1, 37 (1994).

2. V.I. Petrova, Wild-growing fruits and berries, M., 108 (1987).

3. A.G. Smirnov, V.G. Leonchenko, Common viburnum (Viburnum vulgaris), Horticulture and viticulture j., 4, 24 (1998).

4. I.G. Serebryakov, Field Geobotany, M., Nauka publ., 3, 203 (1964).

5. A.L. Takhtadjian, Floret plant phylogeny system, M., Nauka publ., 418-422 (1966).

6. V.I. Deineka, A.M. Grigoryev, L.A. Deineka, E.I. Shaposhnik, V.M. Staroverov, Study of anthocyanins of blueberries in their fruits and blueberry-based preparations by the HPLC-method, Plant Laboratory j. Material Diagnostics, 72, 3 (2006).

7. J.M. Cheeseman, Hydrogen Peroxide and Plant Stress: A Challenging Relationship. Plant Stress, Global Sci. Books, 4-15 (2007).

8. R.A. Nigmatzyanov, V.N. Sorokopudov, A.G.Kuklina, Qualitative characteristics of golden current-berry cultivars (Ribes aureum Pursh) in Russia, Krasnoyarsk State Agricultural University News Bullet., 3 (2020), DOI:10.36718/1819-4036-2020-3-2934.

9. E.A. Solomatina, N.M. Solomatin, V.N. Sorokopudov, O.A. Sorokopudova, N.I. Myachikova, Frum Adina, C. Georgescu, Food Industry j., 21, 4, 555 (2020).

10. F.F. Sazonov, S.N. Evdokimenko, V.N. Sorokopudov, N.V. Andronova, D.N. Skovorodnikov, Acta Horticulturae j., 1277 (2020).

11. R.A. Nigmatzyanov, V.N. Sorokopudov, Krasnoyarsk State Agricultural University News Bullet., 1, 34-39 (2020), DOI:10.36718/1819-4036-2020-1-34-39.

12. D.K. Shapiro et al., Plant. Res. j., 28, 2 (1992). 